\title{
Robert Wise's The Day the Earth Stood Still (Part II)
}

\author{
By Anton Karl Kozlovic
}

Spring 2014 Issue of KINEMA

\section{ROBERT WISE'S THE DAY THE EARTH STOOD STILL PART II: KLAATU AS ALIEN MESSIAH}

\begin{abstract}
In Part I, the author had documented how the SF cult classic The Day the Earth Stood Still (1951) was traditionally perceived as a UFO film with Artificial Intelligence (AI), political, police and philosophical dimensions, and arguing that it is best understood as a profoundly religious film. In Part II, the critical literature was revisited and textually-based, humanist film criticism was again utilized as the guiding analytical lens to explicate the subtextual construction of Klaatu as an alien Messiah within an SF Passion picture. It is argued that Klaatu is the Christ-figure of 1950s science fiction cinema.
\end{abstract}

\section{Introduction}

In the Fall 2013 issue of Kinema: A Journal for Film and Audiovisual Media, the author closely examined the classic black-and-white UFO film The Day the Earth Stood Still. He highlighted the film's anti-nuclear political theme, its AI, police and philosophical readings, and then demonstrated its even more profound subtextual religious nature. In Part II of this analytical triptych, the Christ-figure/ alien Messiah nature of the intergalactic emissary Klaatu/ Carpenter (Michael Rennie) is explicated in detail. Why bother delving deeper? Because the religious resonance of this cult classic did not stop with Klaatu's holy aura or the cosmic rebuking of humanity's xenophobic paranoia; whether induced by fear, rampant nationalism, or the looming threat of Earth's potential apocalyptic annihilation.

The critical literature was revisited and integrated into the text to enhance narrative coherence (albeit, with a strong reportage flavour) utilizing textually-based, humanist film criticism as the guiding analytical lens (i.e., examining the textual world inside the frame, but not the world outside the frame - Bywater and Sobchack; Telotte). It is argued that an essential component of the film's phenomenal success was the deft subtextual crafting of Klaatu as an alien Messiah within an SF Passion picture. This sacred subtext helped transform a potentially ordinary alien film into a cult classic that warranted its 1995 induction into the National Film Registry (Library of Congress) for being culturally, historically, or aesthetically significant.

\section{Klaatu as Alien Messiah}

The tall, slender and handsome Klaatu sounded sophisticated using his resonant voice that the boarding house landlady, Mrs. Crockett (Edith Evanson), assumed was from New England, that is, "cultivated, upper class" (Cranny-Francis 85), whilst clothing-wise (see Figure 1 and Figure 5), Klaatu was suave and looked "good in both a futuristic, nicely tailored silver jump suit and ordinary Earthling wear" (Perkowitz 20). ${ }^{(1)}$

But this assessment is not too surprising considering his official role as a "space emissary" (Magistrale 84) from an "inter-planetary UN" (Stal npn) who had dramatically arrived on Earth in the hi-tech equivalent of a star from heaven. American radar officers on a beach in the Pacific Islands first noticed his star-ship quickly followed by British radar officers tracking its movements from East to West over Hong Kong. Various newscasters reported its progress across India, France, Britain and America wherein a radio announcer informed that it was "heading over the North Atlantic heading towards the east coast of the United States," and easily observed by the astonished local populace (see Figure 2). These radio broadcast directions corresponded with the biblical account of Jesus's moving "star in the east" (Matt. 2:2). ${ }^{(2)}$

Subtextually speaking, the handsome Klaatu is the equivalent of the popular perception of Jesus being physically beautiful, ${ }^{(3)}$ interpersonally awesome in both word and deed, and emanating a tangible spiritual aura. Indeed, when Klaatu emerged from his spaceship he wore a semi-translucent bubble helmet that covered his face (see Figure 1 and Figure 4). Subtextually speaking, this was either: (a) the physical equivalent of Jesus wearing his white head-shroud with toga (much favoured by Hollywood Jesus films) or (b) the physical equivalent of Christ's holy halo (much favoured by religious painters). Klaatu's physical need for a full-face helmet seems superfluous because he does not appear to need it when working inside 


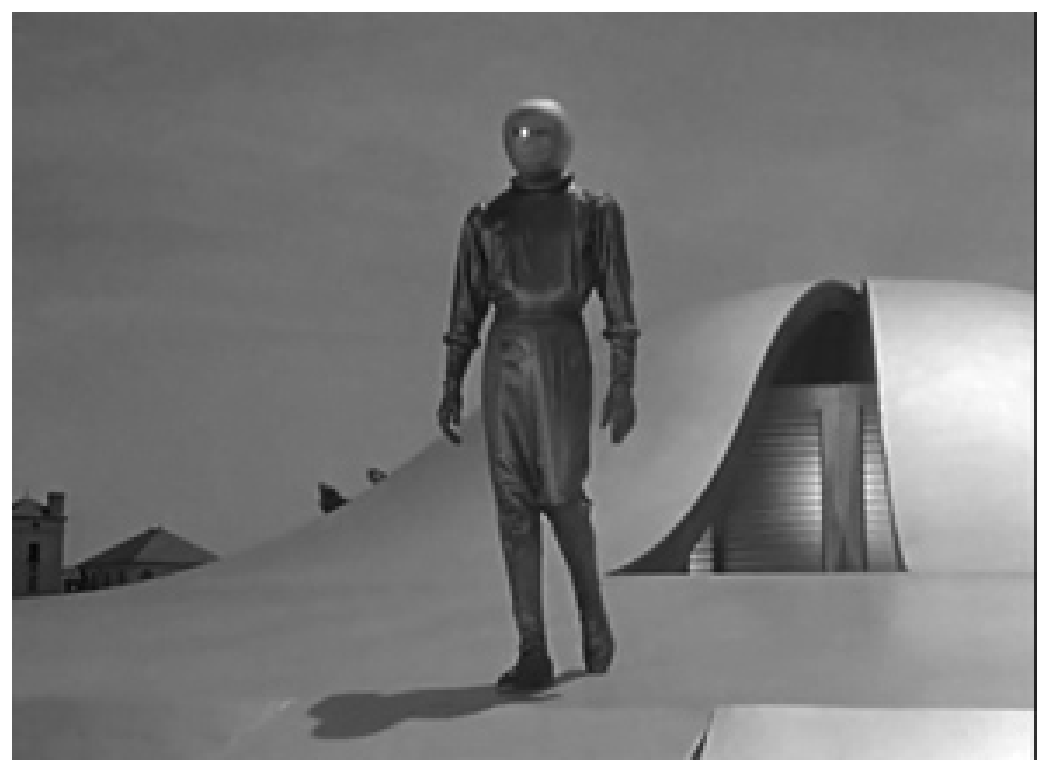

Figure 1: Figure 1: Klaatu as Suave Intergalactic Emissary

his hermetically sealed spaceship, or when sightseeing Washington, or when leaving Earth to return home to the heavens. However, melodramatically speaking, the helmet served the useful purpose of hiding his alien features until the dramatic reveal in hospital. Klaatu was certainly viewed by various commentators in a serious religious light via their descriptions of him as "a saintly interplanetary visitor" (Sayre 196), a "gnostic messenger" (Ellis 168), and "a prophet" (Rogerson online).

When Klaatu landed his silvery flying saucer-shaped star-ship upon a baseball diamond in a large mall in Washington DC (see Figure 3), "the center of all that represents American power and the American way of life" (Henriksen 51), the historical timing of his arrival was deliberate. It was at a critical moment in $20^{\text {th }}$ century world affairs and so Klaatu came "to Earth in order to announce a new covenant between humanity and the universe" (Hewitson 283). In effect, to help deliver humankind from their barbaric selves into a new era of cosmic peace that would indelibly change the course of human history. Klaatu's mission was just like Jesus Christ's mission, that biblically labelled "bright and morning star" (Rev. 22:16) who "came down from heaven" (John 3:13) and took on human form, worked as a "carpenter" (Mark 6:3) then ministered to humanity, and indelibly changed the course of human history in the process.

Hints of the film's christic subtext were given at the beginning of the movie when Klaatu's spaceship, "which could have been mistaken for a star millenniums ago" (Frumkes 34), was first detected by an American military radar installation wherein a soldier exclaimed "Holy Mackerel!" (i.e., a religious euphemism for "Holy Mary" with "Mackerel" being a nickname for Catholics because they ate fish on Fridays). This was quickly followed by a British military installation wherein a soldier exclaimed "Holy Christmas!" (i.e., the divine holiday that celebrated the birth of Christ) when he calculated the spaceship's "4,000" miles per hour velocity. Thereby, "equating the celestial firmament with that of [the] Biblical Heaven" (McCorry online) and linking Klaatu's starlike spaceship with the Star of Bethlehem (aka the Christmas star) that today is prominently displayed upon Christmas trees worldwide. Additionally, this ancient biblical star could move and stop itself unnaturally, as stated in Scripture: "the star, which they saw in the east, went before them [wise men], till it came and stood" (Matt. 2:9). Subtextually speaking, the detecting of this spaceship-star made the radar operators from different countries analogous to the "wise men ... [who] have seen his star in the east" (Matt. 2:1-2), but by using the forecasting tools of navigational science rather than astrological magic coupled to celestial observation.

When Klaatu arrived upon planet Earth, humanity was on the brink of both nuclear proliferation and interplanetary rocket travel, a deadly combination that meant that humankind was on the verge of exporting its violence throughout the universe. This critical stage in human social and scientific evolution had neces- 


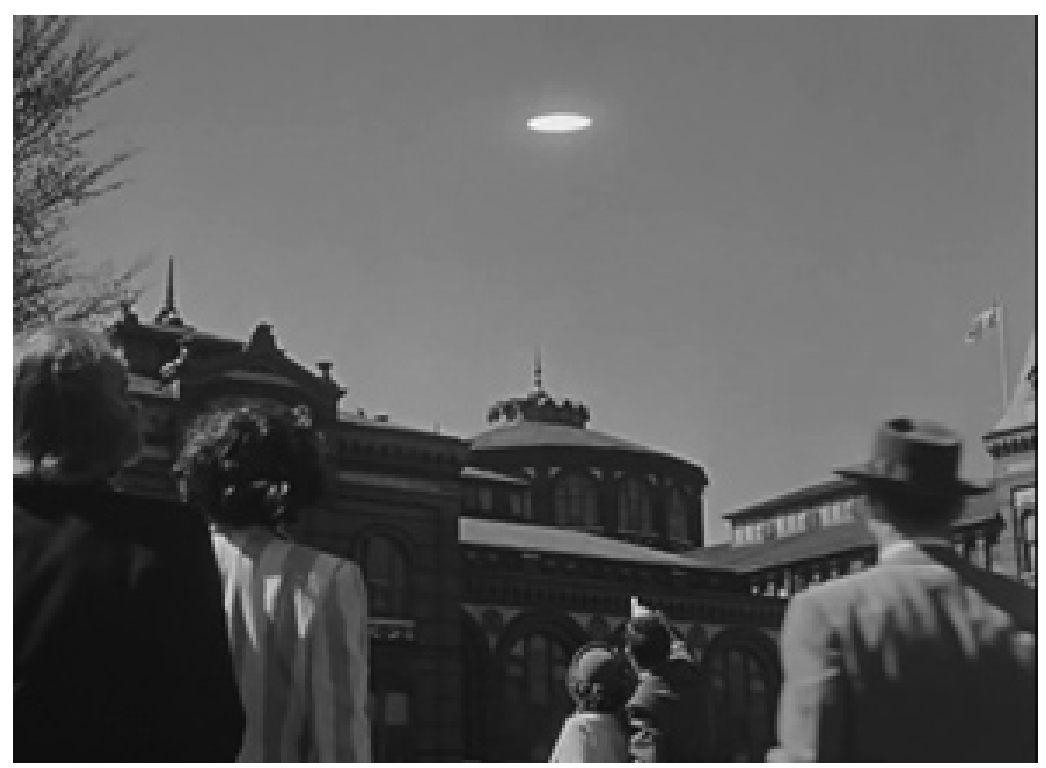

Figure 2: Figure 2: Klaatu's Arriving Star-Ship

sitated Klaatu's pre-emptive act of cosmic intervention on behalf of an advanced collective of alien beings, an "inter-planetary UN" (Stal npn), who closely monitored Earth from afar (akin to God and his heavenly helpers overseeing humankind). This inter-planetary confederation had considered it time for Earth to join their interstellar alliance and so their emissary was sent to offer humanity an incredible political opportunity, and a fabulous physical gift as a good-will gesture.

When the newly arrived Klaatu first left his spaceship, he raised his right hand in a benediction-like pose (see Figure 4) and then loudly announced: "We have come to visit you in peace, and with good will," the same calling card deployed by Jesus Christ, the "Prince of Peace" (Isa. 9:6) who harboured good will to all and frequently addressed people with: "Peace be unto you" (John 20:19, 21, 26). Indeed, the scriptural Jesus was a political outsider and a social eccentric in this regard, just like Klaatu, who encountered in return multiple macho-man military responses. As Tony Magistrale elaborated:

... it is therefore appropriate that the only humans who provide Klaatu with any measure of comfort and support are Helen [Patricia Neal], her adolescent child, Bobby [Billy Gray], and the "misunderstood" mathematician [Dr Barnhardt (Sam Jaffe)]. Woman, child, and intellectual are able to bond with the alien [Klaatu] because they, too, are aliens in this society of militaristic authority and cultural exclusivity (84).

In its day, the profound religious subtext of The Day the Earth Stood Still was not readily detected, but nowadays, many non-religious critics are quick to point out that Klaatu was "a space-traveling Christ figure" (Cousineau 66), or a "highly evolved powerful messiah figure who comes to Earth ... with a force that cannot be denied" (Hendershot 30). Others claimed that: "Klaatu has an unmistakable touch of divinity about him" (Pettigrew 71) because he "represents transcendent power and has come to offer mankind salvation from holocaust" (Saleh 41), albeit via encouraged deadly discipline from above coupled with "the overt Christian philosophy of this so-called federation of advanced beings" (Macek 590).

Indeed, Klaatu was in the world but not of the world, just like Jesus (John 17:13-15), and according to Tony Magistrale, Klaatu was "the ultimate outsider from another planet" (86). Although Klaatu had human-like physiology (as attested to by his medical examination at the Walter Reed Army Hospital), he was of alien origin, just like Jesus who took human form but was of divine (non-earthly) origin, thus making Jesus both human and divine (earthly and alien), as attested by Scripture: "For in him [Christ Jesus the Lord] dwelleth all the fullness of the Godhead bodily" (Col. 2:9).

Whatever Klaatu's ontological nature, his primacy was deftly acknowledged on-screen when he and young 


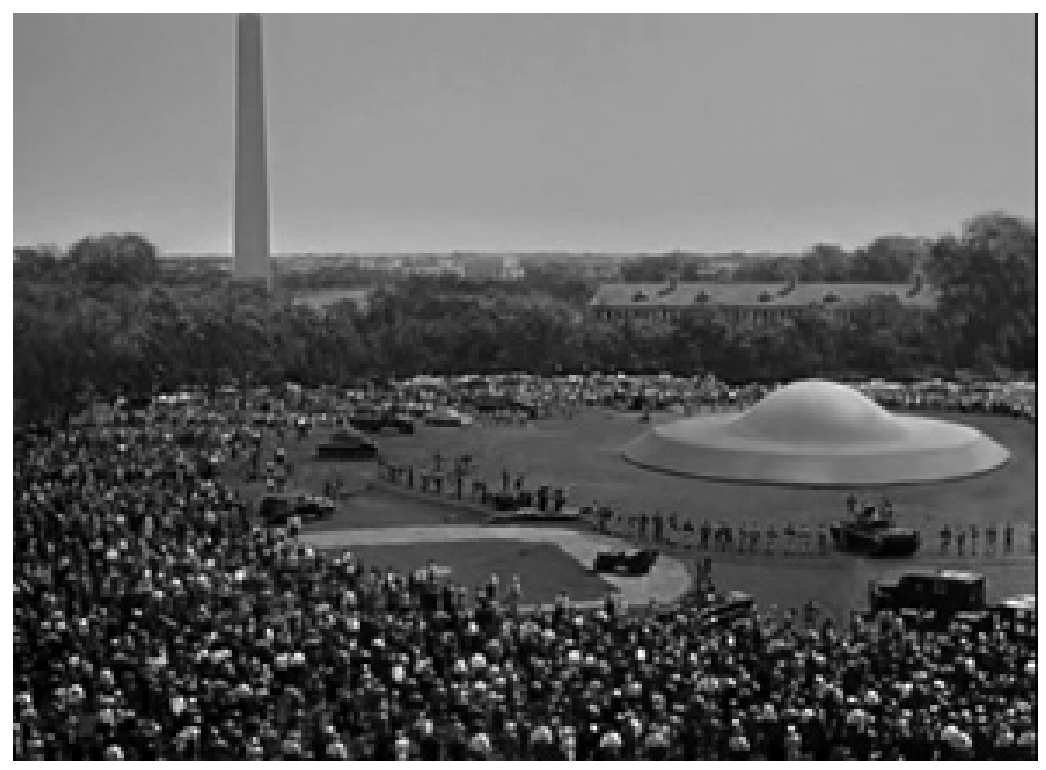

Figure 3: Figure 3: Klaatu's Landed Spaceship in Washington DC

Bobby Benson made "a pilgrimage" (Biskind 152) to the Lincoln Memorial. After reading the Gettysburg Address, Klaatu asked Bobby who was the greatest man in the country and he answered: "The spaceman" (i.e., Klaatu) - out of the proverbial mouth of babes! Furthermore, for Boylston Tompkins, "Klaatu ... is only humanity raised to the tenth power, mysterious, perhaps, gifted with great wisdom, but still killable" (13), but so was Jesus Christ, the human-alien hybrid who was also killable, as attested in Holy Scripture via his crucifixion-death when he "gave up the ghost" (Mark 15:37).

Not only did The Day the Earth Stood Still have a strong altruistic ambience, but as Terence Pettigrew cynically argued: "Calling himself Mr. Carpenter, he [Klaatu] passes of easily as one of us - if anything, he is too genteel and courteous to be one of us" (71; see Figure 5). But once again Klaatu is just like Jesus whose own earthly behaviour was as unorthodox and exceptional in his ancient day as Klaatu's behaviour was in modern-day (1950s) America.

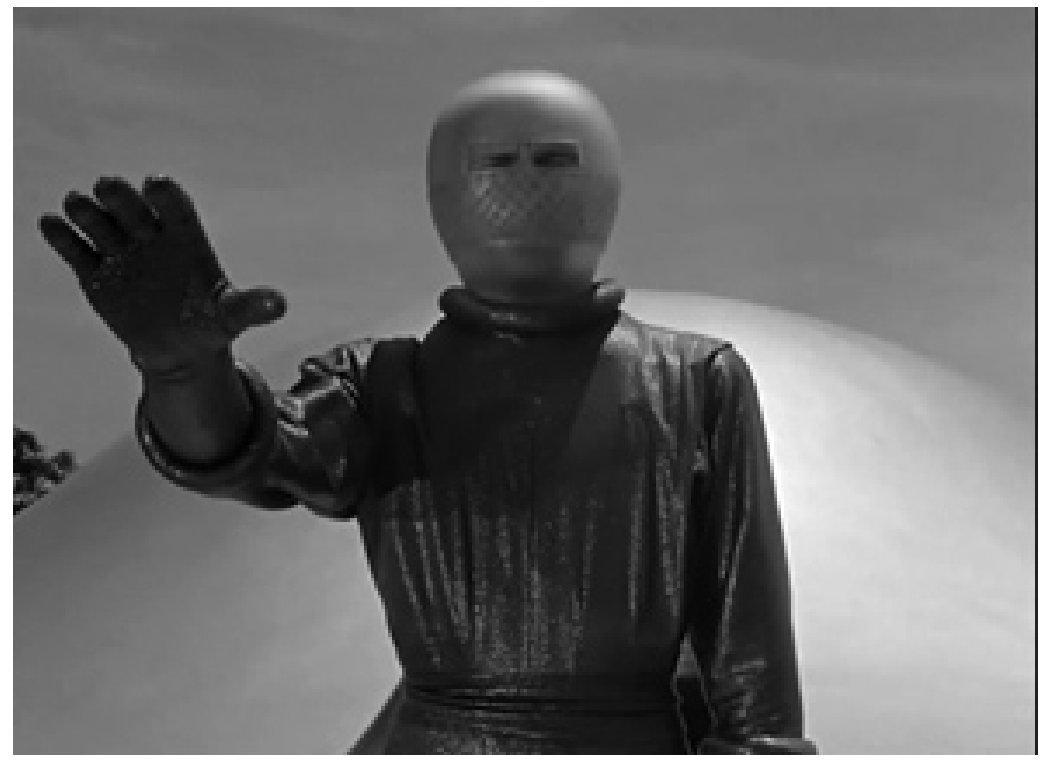

Figure 4: Figure 4: Klaaatu's "Peace and Good Will" Benediction 
Margot A. Henriksen described Klaatu as "mild-mannered" (52) whilst the anonymous critic from The New York Times proclaimed that Klaatu and Gort upon their earthly arrival were "such descent fellows, so wellmannered and peacefully inclined, that you'd hardly expect them to split an infinitive, let alone an atom or a human head" (Canby et al. 196). Therefore it is not too surprising to find that Klaatu-as-Christ-figure displayed this same essential quality and much more. Indeed, Jesus once proclaimed that unless one "become as little children, ye shall not enter into the kingdom of heaven" (Matt. 18:3). It is again not surprising to find Tony Magistrale observing that: "Klaatu's longest and most revealing dialogues take place with young Bobby because the alien is himself childlike. He maintains the same level of awe that a child feels about discovering new worlds; he cannot understand why his simple message is so difficult for earthlings to appreciate" (84).

\section{The Day the Earth Stood Still (1951) as an SF Passion Picture}

Not only was this SF film a cautionary political tale about human aggression that had subtextually constructed Klaatu as an alien messiah, but it was also a "modern retelling of the Christ story" (von Gunden and Stock 43) that turned The Day the Earth Stood Still into a subtextual SF Passion picture (i.e., the end time portion of a Christ cycle film). Like Jesus, Klaatu-as-alien-saviour came from the starry heavens, arrived triumphantly, bore wondrous gifts and offered humanity an unprecedented opportunity for galactic redemption. He was about to present an exotic token of friendship, namely a short, spike-pronged object, which some thought looked like a scroll containing a message (Craft 217), when a frightened, trigger-happy soldier ensconced within the defensive military perimeter that encircled Klaatu and his saucer misconstrued Klaatu's peaceful, gift-giving intention and promptly shot him in the shoulder. In that violent xenophobic act, the soldier accidentally destroyed the alien gift being proffered (see Figure 6), and as the wounded Klaatu ruefully explained: "It was a gift for your President. With this he could have studied life on the other planets," but now its colossal powers is "something we have to take purely on faith" (King and Krzywinska $88)$.

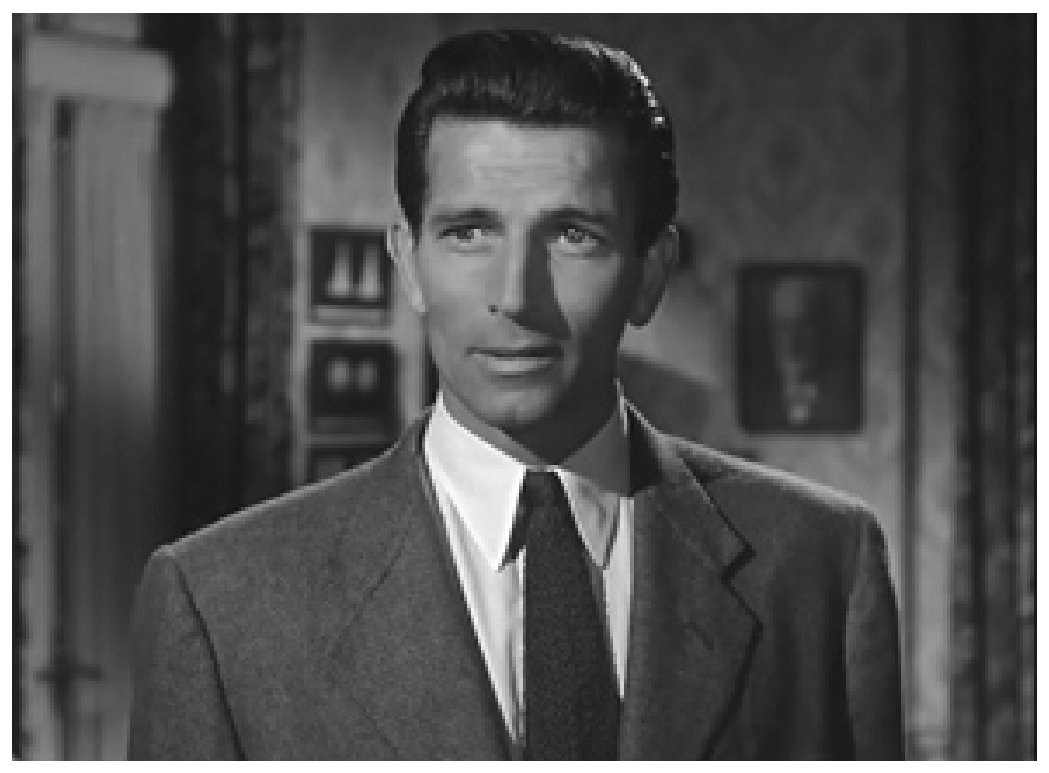

Figure 5: Figure 5: Klaatu as Mr. Carpenter

This regrettable result was similar to many of Jesus's gifts, powers and promises for humanity. Despite his peaceful intentions and human appearance, itself another anthropomorphic restating of the Judeo-Christian tradition of God being like you and me but only better, Klaatu was feared, abused, incarcerated, and forced to flee both military injustice and political stupidity. He was also the victim of an aggressive media smear campaign when sonically tagged a "monster" and a "menace from another world" whilst visually speaking, he was typecast in the newspaper as a criminal with full-facial gangster iconography (see Fig. 7). Indeed, when Klaatu miraculously recuperated from his gun-shot wound and mysteriously escaped his enforced hospital confinement, a radio newscaster (played by real life newscaster Gabriel Heatter) proclaimed: "This creature 
must be tracked down like a wild animal. He must be destroyed!" Subtextually speaking, this aggressive newscaster can be seen as the embodiment of the corrupt Jewish Establishment in Jesus's day who vigorously agitated for Christ's death; as attested within Scripture: "the chief priests and elders persuaded the multitude that they should ... destroy Jesus" (Matt. 27:20).

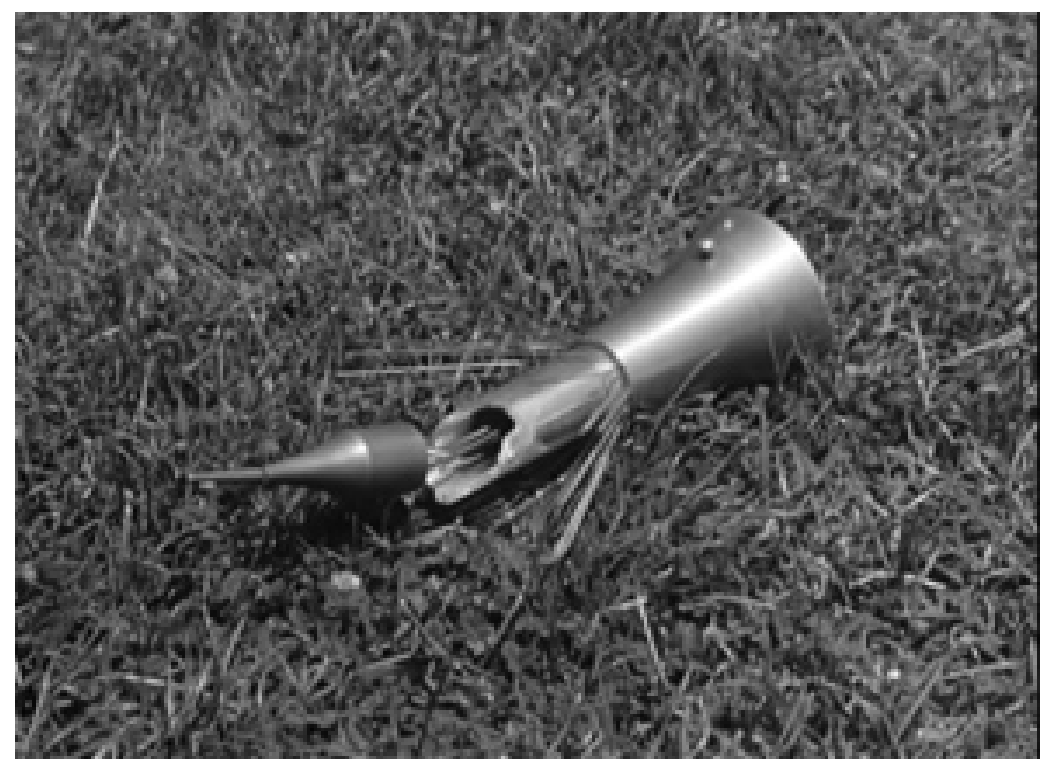

Figure 6: Figure 6: Klaatu's Broken Presidential Gift

Consequently, Klaatu donned the guise of an ordinary Earth-human and wandered the streets incognito like "a stranger in a strange land" (Exod. 2:22) before he acquired lodgings at a boarding house and temporarily lived amongst ordinary people; even if the "household sequences bare the absurdities of films from the 50s (everyone dresses in suits and ties, even when relaxing at home)" (Pfeiffer 182). Klaatu's alter ego nomenclature as "Carpenter," no first name, just "Carpenter" subtextually resonated with the description of Jesus as a "carpenter" (Mark 6:3), but of different sort during his earthly visit.

For some commentators, Klaatu /Carpenter standing in the shadows when he first entered the boarding house (see Fig. 8) was deliberately designed to instil fear (Barone 208-209); however, the writer suggests that projecting a sense of the mysterious was the primary intent. Nevertheless, any projections of fear onto the unknown figure was quickly resolved the moment light bathed his beautiful body. Whilst living inside the boarding house, Klaatu-as-Carpenter was able to get a cross-view of humanity's feelings about the escaped spaceman, complete with left wing, right wing and Communist overtones, especially when Mrs. Barley (Frances Bavier) knowingly equated him with the unnamed Soviet threat as follows: "Well, if you want my opinion, he comes from right here on Earth. And you know where I mean."

Later, Klaatu became distraught at the inhumanity of man to man, and man to alien where bigotry "against aliens by extension becomes the heathen denial of Christ" (Biskind 152). Klaatu was also impatient with humankind's petty political squabbles, of which he would have no part, just like Jesus who refused to play the traditional power politics of his ancient day; as deftly demonstrated by his trap-avoiding advice: "Render to Caesar the things that are Caesar's, and to God the things that are God's." (Mark 12:17). Unfortunately:

... Klaatu's messianic mission is opposed by stereotypical representations of a warmongering military, xenophobic citizens (represented by the inhabitants of the boarding house), and an amoralistic publicity seeker (Tom Stevens). Heroic Americans (Helen Benson, Bobby Benson, and Dr. Barnhardt) who defy prejudice and recognize a messiah when they see one aid Klaatu (Hendershot 28).

The subsequent failure to capitalise upon Klaatu's fantastic opportunity for humanity, and to surpass the confines of their earthly existence, was not appreciated by contemporary officialdom, just like ancient offi- 


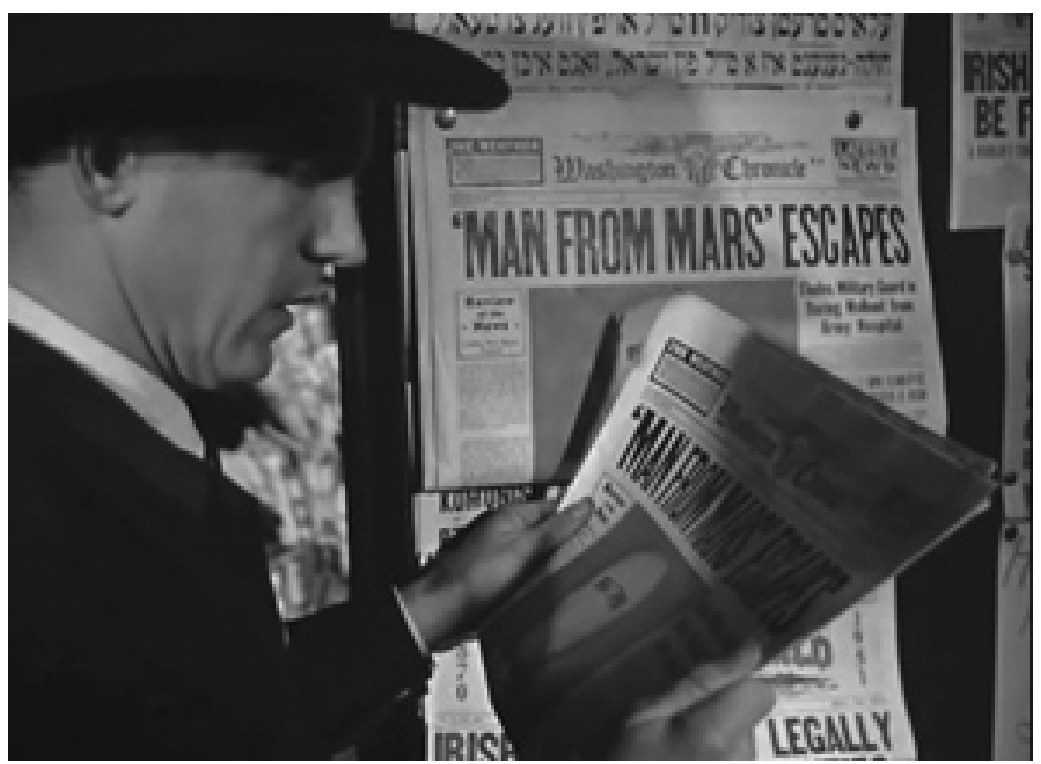

Figure 7: Figure 7: Klaatu, the Martian Menace

cialdom in Jesus's day wherein the terran political, military and religious representatives were content to maintain the status quo and so chose to eliminate the source of their displeasure (i.e., Jesus).

In addition to skilful subtextual plotting, deft dialogue and spooky special effects, the emotional crafting of Klaatu's otherworldly Christ-figure nature was dramatically enhanced by Bernard Herrmann's musical scoring of the film. Particularly, his deployment of electronic instruments such as "two theremins, high and low, electronic violin, electronic bass, and electronic guitar" (Bruce 104) coupled with Herrmann's musical intent to create feelings of eeriness and otherworldliness. As he claimed: "My goal here was to characterize a man from another world, and the music had to reflect an unearthly feeling of outerspace without relying on gimmicks" (Bruce 104). He succeeded admirably for his score is filled with forceful alien beauty that became classic signature sounds for Klaatu, Gort and outer space in general. However, the author rejects Dennis Barone's claim that: "Herrmann's music for the film is always scary, never reassuring" (211).

Just as interesting, although the film was black-and-white, colour stills from the production show Klaatu wearing a blue spacesuit (see Siegel and Suares 35; von Gunden and Stock dust cover). Biblically speaking, blue is the symbolic colour of "the heavenly origins of Christ (as the sky is blue)" (Owen, Grist and Dowling 9). Symbolically speaking, blue is also "the color of the divine, of truth, and of fidelity (in the sense of clinging to truth, as well as with reference to the fixed firmament of heaven) ... blue is also a purity symbol" (Matthews 25). Therefore, Klaatu's christic nature was correctly colour coded on-set if not on-screen in a black-and-white filmic world.

The theme of christic otherness and christic rejection was also evident by the military's treatment of Klaatu, Gort, their spaceship and the exotic alien gift. As Tony Magistrale pointed out regarding the inadvertent destruction of this gift:

The symbolic opportunity to view life in alien galaxies is forfeited ... in favour of remaining selfenclosed and self-insulated (the army constructs a wooden fence that encircles the spacecraft and also encases Klaatu's robot in a thick block of plastic). Although easily overlooked in the larger design of the movie, the device that Klaatu wishes to present to the president is a priceless gift with unlimited potential to inspire and advance the celestial imagination. No one laments or apologizes for its destruction, indicating that no human in the film is capable of appreciating the opportunity that has been wasted; the same can be said about the general failure to appreciate the uniqueness of Klaatu's personality and long-distance message (85).

This same point can be made about the ancient Jewish and Roman lack of understanding concerning the 
cosmic uniqueness of Jesus (i.e., divine-human nature) and his long-distant message delivery service (i.e., from God in faraway heaven to Earth).

\section{Klaatu's Crucifixion, SF Style}

Despite Klaatu's cadre of earthly "disciples" and his (literal) universal message that counselled peace, he was denied, rejected, pursued, cornered and then killed by human ignorance and intolerance (parallelling Jesus's earthly experiences). Klaatu's Christ-figure status was visually confirmed when the military went on their own version of a holy crusade and shot him for being a dangerous prophet-at-large (analogous to the Roman soldiers' pursuit, capture, piercing and crucifixion of Jesus to preserve the military, political and religious status quo of their ancient day). Furthermore, when Klaatu fled the pursuing military during the night and was shot once in the back, he twisted around, grabbed his side, indicating the wound site (akin to Jesus's pierced side - John 19:34), crashed onto the ground, and landed in a classic cruciform pose, complete with splayed arms and appropriately bent knee (see Figure 9).

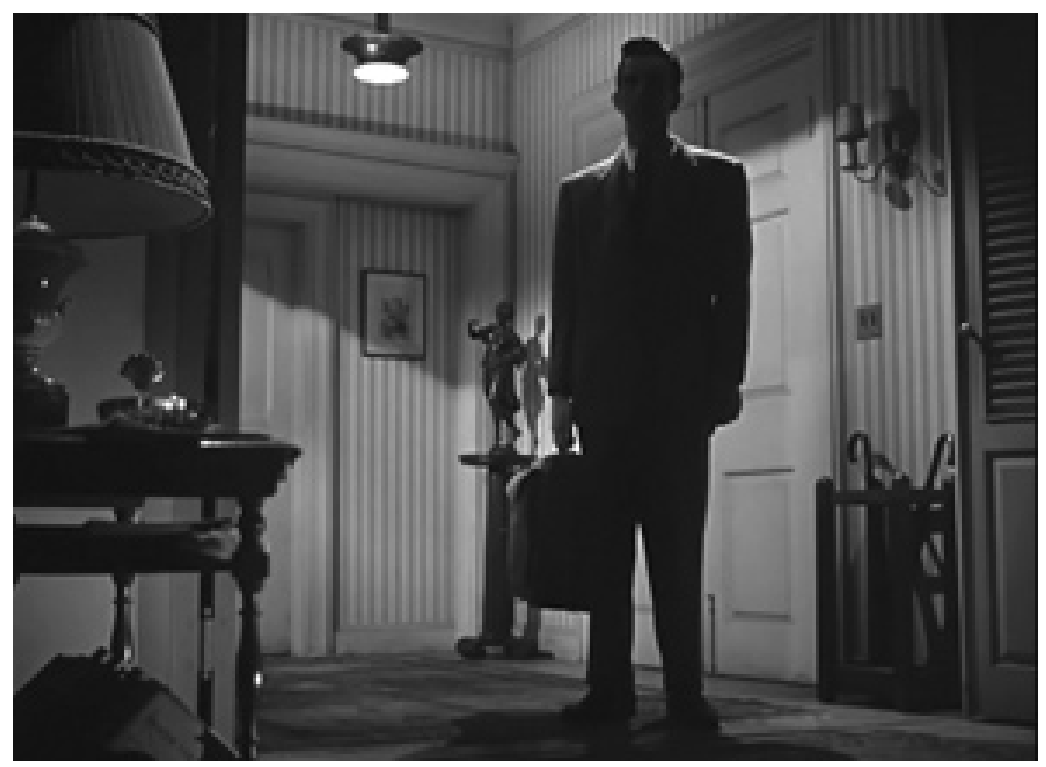

Figure 8: Figure 8: Mr. Carpenter in Shadow

This cruciform pose is much favoured throughout history by religious artists; as is the depiction of darkness over the land during Jesus's death (Mark 15:33). Upon closer inspection of this night time scene, when the body is visually coupled with the "innocent" positioning of the street guard rail with its identification sign (left hand side), it could be creatively perceived as Jesus's upright crucifixion beam with "INRI"-style sign posted above his head. This interpretation is more easily appreciated when the film's death scene is rotated ninety degrees (Fig 10).

The cruciform pose is the ultimate christic identifier (as indicated by millions of Christians wearing crucifixes throughout history) that makes "it easy to construe Klaatu as a Christ figure who sacrifices his life in order to preserve civilization" (Macek 590). Indeed, immediately prior to his death, when Klaatu urgently spoke to Helen Benson, his fears were not for himself, but for the fate of all humankind (for if the activated Gort was not stopped, it would destroy Earth), thus further demonstrating Klaatu's Christ-like selflessness. However, Klaatu's Christ-figure nature is even more powerfully buttressed by a palpable resurrection scene.

\section{Klaatu's Resurrection, SF Style}

Klaatu's military-pierced body is confirmed dead and stored inside a brick police cell, which is analogous to Jesus's stone burial sepulch re (John 19:42). He is subsequently retrieved by Gort, who is analogous to "the angel of the Lord ... His countenance was like lightning" (Matt. 28:2); especially when Gort burned through the cell wall with his laser beam eye, and then carried the dead Klaatu, Pieta-like, to his spaceship, itself a local celestial abode. The now empty prison cell is analogous to Jesus's empty tomb after he had risen (Matt. 28:6). When Klaatu's body is positioned inside his spaceship, that hi-tech cave of steel with 


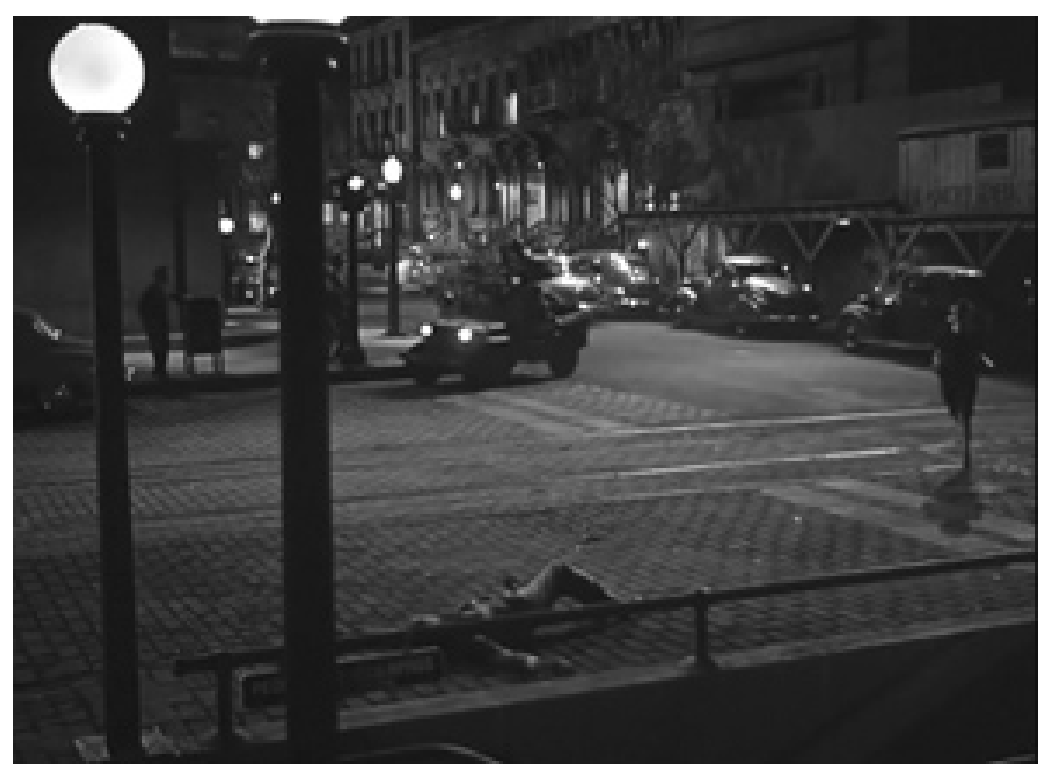

Figure 9: Figure 9: Klaatu's Crucifixion Pose

its "Platonic virtues of clarity, sanity, and reason" (Sobchack 76), a corona-like energy discharge began and "Klaatu's head glows in the rings of the resuscitation machine as though halos shine at his forehead" (Saleh $47)$.

This corona-like energy discharge-cum-hi-tech halo is subtextually analogous to the Gloriole of Christ, that halo/nimbus that adorns the head of the divine, and which is visually depicted in numerous Christ portraits throughout history. This religious interpretation is more easily appreciated when the film's resuscitation bed scene is rotated ninety degrees (see Figure 11). A short time later, accompanied by electronic humming and then urgent beeping sounds that reached a crescendo, the dead Klaatu is "miraculously resurrected" (Shapiro 81) in "a science fiction version of the Ascension" (Saleh 41). Klaatu's alien resuscitation science is therefore directly analogous to the recorded biblical resurrection miracle.

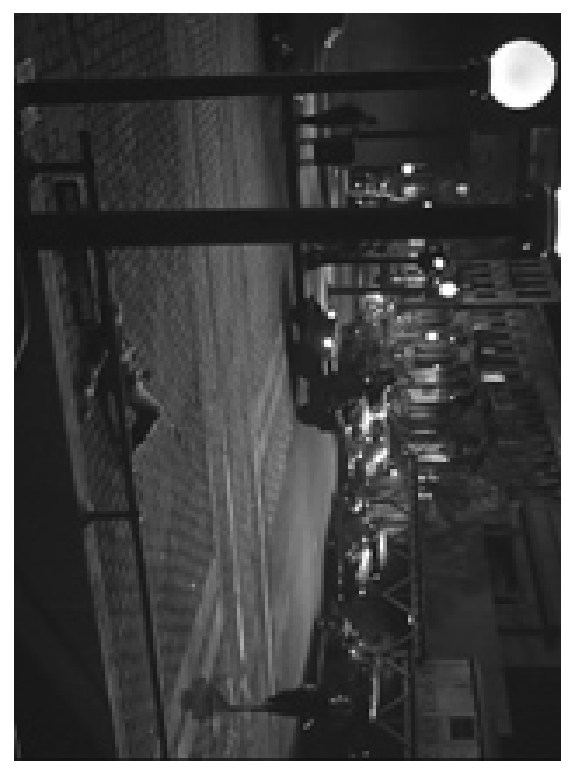

Figure 10: Figure 10: Klaatu's Crucifixion on a Crossbeam 
As James Shaw succinctly described Mr. Carpenter's Passion experiences, the "moment he appears on Earth, Klaatu is rejected, executed, resurrected and, for humanity, ultimately provides an opportunity for redemption. In the truest sense, his life is sacrificed for the preservation of mankind" (52). In fact, Klaatuthe-suffering-Christ-figure escaped death not once but twice. His earlier wounding by the twitchy solider upon his arrival on Earth is distantly analogous to baby Jesus's near death incident when Herod the Great, the King of Judea ordered all boys two-years old and under in Bethlehem to be slaughtered, but Jesus escaped (Matt. 2:1-23). As Laura Long put it: "Just as Jesus Christ worked miracles yet allowed himself to be vulnerable, Klaatu's abilities do not prevent him from encountering the same dangers humans must face in a world of free will" (27). Indeed, the "identification of the alien Other with the suffering Christ is rendered even more powerful by the film's radical pacifism" (O'Leary 404).

Before returning home to his heavenly abode, the risen Klaatu "emerges from his ship like Christ from the tomb and delivers a sermon to the assembled scientists" (Gabbard 152), who are to "become his earthly representatives charged with warning the heretical" (Shapiro 81). Unlike many SF films, these male and female scientists from around the world are not depicted as evil, mad or foolish, but rather, as the future hope of humanity precisely because of their rationality, whom Jerome F. Shapiro had referred to as "the scientific wise men and women" (81). Interestingly, this phrase resonated with the encounter of the wise men who visited baby Jesus for a short time (Matt. 2:7-12), and of the adult Jesus who wanted to show up the foolishness of the wise men of his day (1 Cor. 1:19, 27; 3:20). Similarly, as Klaatu effected this when he easily worked out the mathematical problem in celestial mechanics that had stumped Prof. Barnhardt (see Figure 12). The solution was a scientific revelation to the professor which was made even more potent by Klaatu/Carpenter as its intellectual source, savvy problem solver, and practitioner-cum-successful interplanetary traveller.

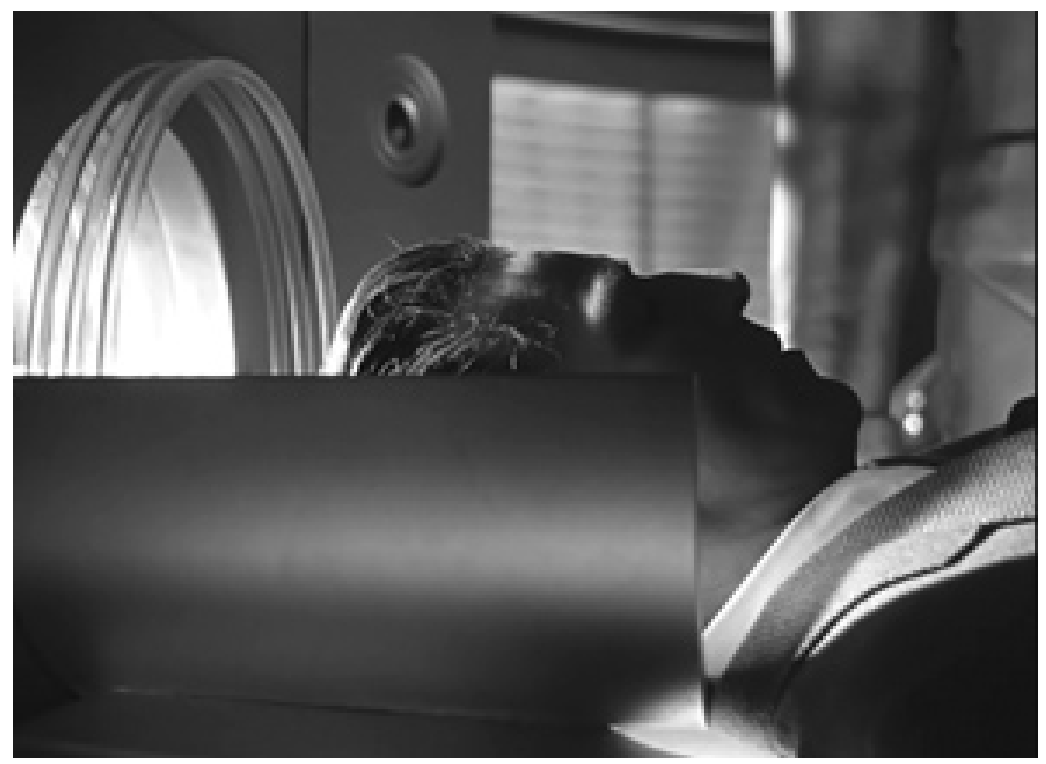

Figure 11: Figure 11: Klaatu's Hi-tech Halo

Klaatu's enthralling sermon quickly turned into a terrifying ultimatum that amounted to potential apocalyptic obliteration, which subtextually resonated with Judgment Day, Christianity's Armageddon (Nicolas; O'Leary; Stone). As Klaatu-the-eschatological-saviour pungently preached: "It is no concern of ours how you run your own planet, but if you threaten to extend your violence, this Earth of yours will be reduced to a burned-out cinder. Your choice is simple: join us and live in peace, or pursue your present course and face obliteration." His stark choice for Earth was akin to Jesus's advice to humanity, namely: "No man can serve two masters ... Ye cannot serve God and mammon" (Matt. 6:24), but remember: "He that is not with me is against me" (Matt. 12:30). As Terence Pettigrew put it: "Straying little from the Church's teachings, Klaatu's recommendations are voiced with the calm authority of "Someone Who Knows'" (71). Klaatu, like Christ, will definitely do something quite drastic at his Second Coming to planet Earth. 
At the end of The Day the Earth Stood Still, Klaatu simply "ascends to the heavens" (Shapiro 81) and went back to the galaxy HQ from whence he came. He "did not marry Helen Benson, get a job at Brookings, and settle down in Chevy Chase" (Biskind 72). But this is not too surprising for a Christ-figure because Klaatu was just like Jesus Christ who also departed Earth when he could have easily ruled it, after all as Jesus claimed: "Thickest thou that I cannot now pray to my Father, and he shall presently give me more than twelve legions of angels?" (Matt. 26:53). Klaatu had Gort, plus the other roving intergalactic policemen, and the rest of the galactic federation to back him up, if desired. Furthermore, Jesus did not marry a nice Jewish girl, get a job at the Temple as a Rabbi (possibly his old job back as a carpenter in his father's business), or settle down in Nazareth to father a family. Why? Because that was not Klaatu's (or Jesus's) purpose, instead, The Day the Earth Stood Still "recapitulates the events of the Passion: He is wounded and eventually killed, but he is resurrected in time to deliver his message" (Tompkins 20) thus fulfilling his earthly mission.

\section{The Day the Earth Stood Still (1951) and Apocalypticism}

If Earth chooses wisely they will live in glorious peace under "the transcendent ethical ideal of nonviolent benevolence" (O'Leary 405). Just like Jesus who promised that: "The kingdom of heaven is at hand" (Matt. 10:7) and after his Second Coming, there will be a 1,000 year reign of peace on Earth (Rev. 20:2-7). Indeed, "Klaatu makes clear that the end of the world - like the Last Judgment - may be sooner than we think" (Gabbard 152). If humanity does not choose Klaatu's path of peace, they will end up like a "burned-out cinder." Just like Jesus's claim that: "The Son of man shall send forth his angels, and they shall gather out of his kingdom all things that offend, and them which do iniquity; And shall cast them into a furnace of fire" (Matt. 13:41-42). In short, as Peter Rogerson succinctly put it: "If peace by love is rejected, then there will be peace by terror" (online). For Jeff Rovin, Klaatu's sermon on top of his spaceship pulpit is "the finest soliloquy in science-fiction-film history" (86) and the writer argues that much of its intrinsic power was due to its New Testament resonating subtext; especially in a world infused by centuries of Christian stories, legends and lore.

After that stern sermon, the post-resurrection Klaatu and Gort promptly entered their flying saucer and physically departed skywards (see Figure 13), which had a strong "New Testament Ascension feel about it" (Pettigrew 7), just like the post-resurrection Jesus who after addressing his followers ascended "into heaven itself" (Heb. 9:24) now that his earthly mission was completed. In the meantime, the "god-like forces he represents will be watching the people of Earth to see that they uphold his teachings of peace and disarmament. Like Jesus in Matthew 28:20, Klaatu is with us "always, even unto the end of the world" (Gabbard 152). The phenomenal powers Klaatu demonstrated on Earth "become powers to be worshipped and adored" (Jancovich 45) as a form of deified science. Much like the miraculous powers exhibited by Jesus are adored today by true believers (e.g., extraordinary healings - Matt. 10:1, and as demonstrated when Klaatu quickly healed himself inside the military hospital).

Thus Klaatu, as the subtextual "image of the messiah serves to give hope, and purpose, and to provide solutions in a world that is seemingly doomed" (Lindohf 195), or as Bonnie Brain put it regarding the essential characteristics of a Christ-figure: "The alien, blameless for our cultural and technological malaise, is the innocent who can redeem us from our sins, and the prophet who can give hope of a future" (229), thus parallelling the saviour, redeemer and pastoral functions of the historical Jesus. However, for the cynic, the religious subtext of The Day the Earth Stood Still can be seen as a pop culture example of a manipulative political strategy, namely, the co-opting of religion to mask politics because the film uses "the Christ / Klaatu parallel to provide a "transcendental" authority supporting a strategy of totally destructive response to expansionist behavior" (Torry 14). Furthermore, the film "is also the single most significant box office film to embody the "technological angels" theme articulated by Carl Jung. Jung may even have had this film in mind when he wrote about flying saucers as quasi-divine beings - technological saviors for an age that could no longer believe in traditional supernatural beings" (Lewis 102).

\section{Not Accidental but Deliberate Religious Film Crafting}

The film's christic subtext was not accidental, wishful thinking or a rose-coloured glasses reading, but rather, its sacred subtext was deliberately crafted, albeit confessed many years later. The film's screenwriter:

... Edmund H. North himself admitted that the parallels between the story of Christ and Day 


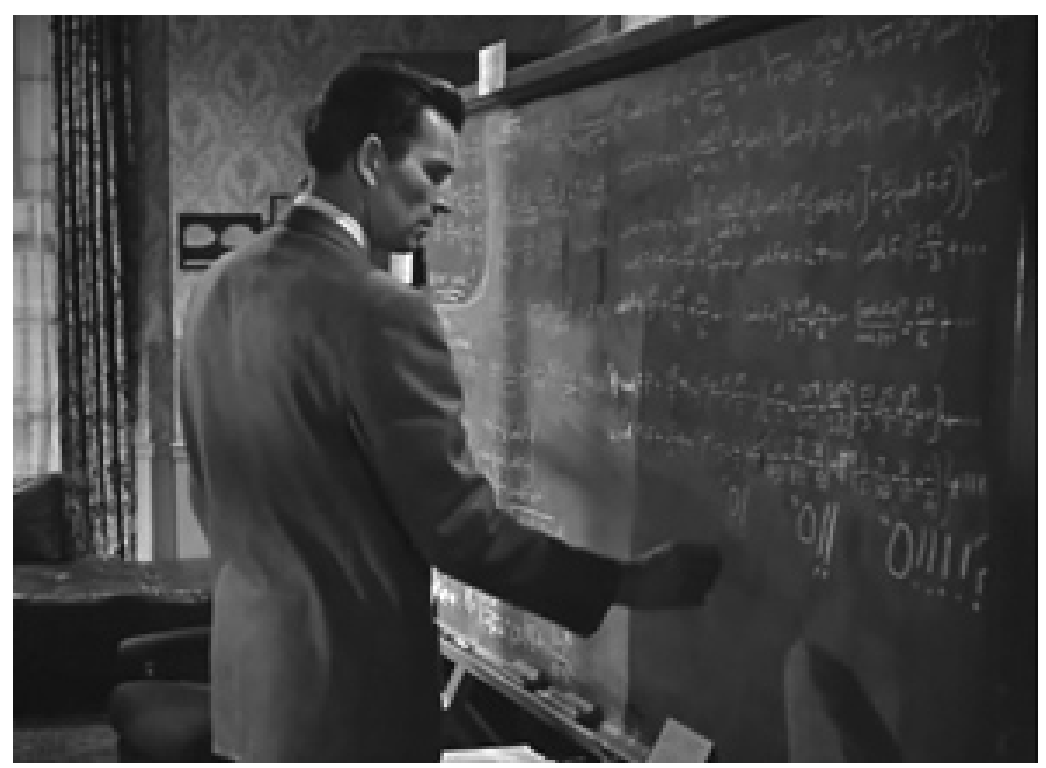

Figure 12: Figure 12: Klaatu, the Celestial Mathematician

were intentional: from Klaatu's earthly name of Carpenter, to the betrayal by Tom Stevens, and finally to his resurrection and ascent into the heavens at Day's end. "It was my private little joke. I never discussed this angle with [producer Julian] Blaustein or [director Robert] Wise because I didn't want it expressed. I had originally hoped that the Christ comparison would be subliminal (von Gunden and Stock 44).

And as North confessed elsewhere: "I didn't honestly expect audiences to pick up the allusion ... I never wanted it to be a conscious thing, but I thought it had value being there" (Warren and Thomas 26).

In fact, North had discarded almost all of Harry Bates' original storyline (Bates). As he admitted: "All we used from the story was this much: A spaceship lands in Washington, D.C. with a man and a robot on board. The original story went off in other directions. What I did was create a new story, and then write the screenplay" (Duncan and Bohus online). Consequently, North was not faithful to Bates' storyline, but to the christic subtext and its higher textual source - the Bible. According to James Shaw, North designed a story structure which postulated the following four metaphors, namely: (a) Universe $=$ World; (b) Planets $=$ Nations, (c) Robots = Armed Forces, and (d) Klaatu = Christ (50). Additionally, Phillip L. Gianos identified four other basic motifs, namely: (a) Earth is a community of all nations, (b) the primacy of military versus civilian authority, (c) great power restrained, and (d) Earth as dystopic (135). So it is not too surprising to find Krin Gabbard claiming that: "none of the major political or religious elements of the film can be found in the short story" (151), "Klaatu in "Farewell to the Master" is no Christ figure: he does not preach; he has no disciples and no betrayer" (152). ${ }^{(4)}$

Furthermore, North went to the trouble of cleaning up any story elements from Harry Bates' novelette that may have significantly conflicted with his hidden christic construction. For example: "Bates's use of a bird and a gorilla - as part of the "resurrection" procedure Gort employs to revivify Klaatu - were eliminated to simplify the plot and keep it credible for a general audience" (von Gunden and Stock 40). However, "credible" should be re-read as "Gospel consistent." In fact, a more deeply constructed christic subtext was thwarted by outside censorship interference in its day. Klaatu was not a better Christ-figure because, ironically:

... the Breen Censorship Board objected to Gort's [Lock Martin] bringing Klaatu [Michael Rennie] back to life, insisting that "only God can do that!" When the board remained adamant in the face of North's argument that the movie was science fiction and dealt with legitimately unearthly powers, a compromise was reached. In the film, Helen Benson tells Klaatu that she thought he was dead and he replies that he was. Helen looks at Gort in awe and says, "You mean he has the 
power of life and death?" Klaatu replies gravely, "No, that is a power reserved to the Almighty Spirit." Klaatu's resurrection is only temporary; he will live, but no one can say for how long. Only the Almighty Spirit and the Breen office have the power (von Gunden and Stock 44).

However, given that the (onscreen admitted) 78-year-old Klaatu supposedly had a life expectancy of 130 years (also admitted onscreen), one wonders how long he really has got to live, certainly not immortality that the resurrected 33 year old Jesus Christ supposedly has. Interestingly, even Klaatu's compromise reply resonated with the Gospels' distinction between Jesus and God for as Jesus said: "it is written, Thou shalt worship the Lord thy God, and him only shalt thou serve" (Matt. 4:10). All of the above belies Warren and Thomas' dismissive claim that:

The principal resemblances between Klaatu and Jesus Christ are in the Earth name the spaceman adopts when he flees the hospital, which is Carpenter, and that he does indeed die and is resurrected. But that's about the limit of it. The religious parallels are mostly playfulness on the part of North, and doesn't really exist to serve as a counterpoint or subtext to the film. Certainly we don't respond (even unconsciously - although who can say?) to Klaatu because he reminds us of Jesus (26-27).

And yet, an otherworldly man called Carpenter who came from the heavens to Earth, died and then is resurrected should be enough to indicate a subtextual Christ-figure (Kozlovic Cinematic)! In fact, the parallels are far greater than Warren and Thomas implied.

\section{The Resistance to Religious Interpretation: Fair?}

As demonstrated, the religious dimension of this SF film is real, substantial and deliberately crafted. It was not the result of some fanciful (or desperate) desire to find Jesus hidden in popular fare. Indeed, in many instances, the precise reverse is the case for many atheists desperately desiring not to see religious elements built into their popular science fiction films, and for essentially unwholesome reasons. Some critics appear to believe that "science" and "religion" are (supposedly) mutually exclusive categories and so when The Day the Earth Stood Still subtextually linked them, then it was somehow in "error" which led to undesirable outcomes. Mark Jancovich exemplified this attitude when he said:

Indeed, this sequence [Gort using technology to bring Klaatu back from the dead] also gives science religious overtones ... Klaatu does tell Helen that his resurrection is only temporary and that only God can give back life once it has been taken, but this only further associates technology and science with the powers of God. They become powers to be worshipped and adored (44).

Yet, logically speaking, from a religious perspective, is not God supposedly the first scientist, the ultimate scientist, the creator of heaven and Earth? And presumably all the physical laws upon which it operates and what scientists are slowly (re-)discovering through their industrious endeavours? So, why should "science" and "religion" not be linked? The "war" between them is old, ill-conceived and dying, and it is slowly being replaced by an emerging new era of rapprochement:

There is little doubt that we are undergoing a paradigm shift of such significance that a new era in the history of science and theology is being heralded ... gone are the days when it could safely be assumed that theology and science had little or nothing to do with one another (Worthing 10-11).

The Day the Earth Stood Still had subtly reflected this paradigm change half a century ago! Indeed, the SF genre is a rich source of contemporary religiosity which can be mined more fruitfully in the future, especially for those who have eyes to see and ears to hear (Ezek. 44:5). As Boylston Tompkins insightfully noted: "science-fiction film ... [is] technology's version of theological speculation" (20), and as Gerard Loughlin pointed out regarding aliens and the divine: "To love God and be loved by God is, on the face of it, the love of aliens; a love that is most to be desired and feared" (42). And if aliens or alien science is to be worshipped, then it should be done out of respect, awe, love and clear, rational, common sense.

\section{Conclusion}

Not surprisingly, Carl Macek called The Day the Earth Stood Still "a masterful piece of entertainment" (590), von Gunden and Stock called it "one of the best science fiction films of the fifties - indeed, of any decade" (38), 
while Phillip L. Gianos called it "an extraordinary mix of science fiction, religion, and political philosophy" (137). One can only agree with them wholeheartedly. Indeed, not only was Klaatu a Christ-figure, but this holy construction was firmly buttressed by interlocking subtextual support characters, including disciples and a betrayer, which will be explicated in the final instalment of this analytical triptych.

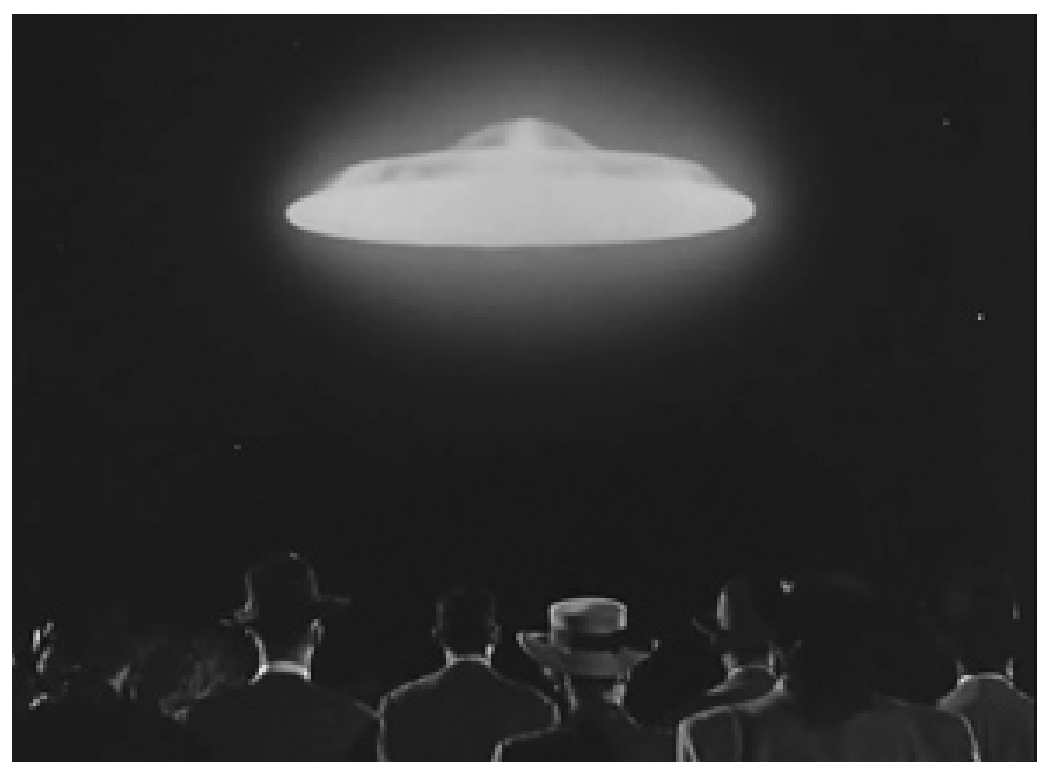

Figure 13: Figure 13: Klaatu's Hi-Tech Ascension

\section{Notes}

1. The film is black-and-white and so the colour of Klaatu's clothing looks silvery; however, from colour stills of the film, Klaatu's suit is actually a shiny blue (see the dust cover image from von Gunden and Stock).

2. The Authorized King James Version of the Bible (KJV aka AV) will be used throughout, unless quoting other translations, because most of the biblical phrases that are embedded in Western culture are from the King James Version, which is one of the most widely used English translations today (Taylor ix, 71).

3. Biblically speaking, there is no physical description of Jesus Christ. He was possibly ugly or deformed if one accepts the description of the Lord-to-come described in Isaiah 53:2-4, namely: "when we shall see him, there is no beauty that we should desire him ... and we hid ... our faces from him; he was despised, and we esteemed him not ... stricken, smitten of God, and afflicted." Yet, only foolish filmmakers would dare portray an ugly or deformed Jesus, and by implication suggest an ugly or deformed God; especially if making a physical interpretation of Jesus's claim: "If ye had known me, ye should have known my Father also: and from henceforth ye know him, and have seen him" (John 14:7).

4. Ironically, "Master" is a word used to describe Jesus (Luke 17:13) and even Jesus called himself "The Master" (Matt. 26:18), and so Bates's story did have at least one significant Jesus-link! Throughout the production process, Wise's film name changed from The Man from Mars to Farewell to the Master to The Day the World Stopped to The Day the Earth Stood Still (Fischer 684).

\section{References}

\section{Works Cited}

Barone, Dennis. "Klaatu was No Angel: A Historical-Contextual Analysis of The Day the Earth Stood Still." Studies in the Humanities 23.2 (1996): 202-12. 
Bates, Harry. "Farewell to the Master." Reel Future. Eds. Forrest J. Ackerman and Jean Stine. New York: Barnes and Noble, 1994. 146-79.

Biskind, Peter. Seeing is Believing: How Hollywood Taught us to Stop Worrying and Love the Fifties. New York: Pantheon Books, 1983.

. "Pods, Blobs, and Ideology in American Films of the Fifties." Shadows of the Magic Lamp: Fantasy and Science Fiction in Film. Eds. George E. Slusser and Eric S. Rabkin. Carbondale: Southern Illinois University Press, 1985. 58-72.

Brain, Bonnie. "Saviors and Scientists: Extraterrestrials in Recent Science Fiction Films." Et cetera 40.2 (1983): 218-29.

Bruce, Graham. Bernard Herrmann: Film Music and Narrative. Ann Arbor, MI: UMI Research Press, 1985.

Bywater, Tim, and Thomas Sobchack. An Introduction to Film Criticism: Major Critical Approaches to Narrative Film. New York: Longman, 1989.

Canby, Vincent, Janet Maslin, film critics of The New York Times and Peter M. Nichols, eds. The New York Times Guide to the Best 1,000 Movies Ever Made. New York, NY: Times Books/Random House, 1999.

Cousineau, Phil. UFOs: A Manual for the Millennium. New York, NY: HarperCollins West, 1995.

Craft, Michael. Alien Impact: A Comprehensive Look at the Evidence of Human-Alien Contact. New York: St. Martin's P, 1996.

Cranny-Francis, Anne. Multimedia: Texts and Contexts. London: Sage, 2005.

Duncan, Jay, and Ted Bohus. Interview: Edmund H. North Screenwriter. SPFX: Special Effects Magazine 2 (1977): http://www.dreamerwww.com/spfx/spfx2.htm. Online March 30, 2001.

Ellis, Caron S. "With Eyes Uplifted: Space Aliens as Sky Gods." Screening the Sacred: Religion, Myth, and Ideology in Popular American Film. Eds. Joel W. Martin and Conrad E. Ostwalt Jr. Boulder: Westview Press, 1995. 83-93, 167-69.

Frumkes, Roy. "Those Elite Laser Specials." Films in Review 46.7/8 (1995): 31-34.

Gabbard, Krin. "Religious and Political Allegory in Robert Wise's The Day the Earth Stood Still." Literature/Film Quarterly 10.3 (1982): 150-54.

Hendershot, Cynthia. Paranoia, the Bomb, and 1950s Science Fiction Films. Bowling Green, OH: Bowling Green State U Popular P, 1999.

Henriksen, Margot A. Dr. Strangelove's America: Society and Culture in the Atomic Age. Berkeley: U of California P, 1997.

Hewitson, James. "Film." Encyclopedia of Millennialism and Millennial Movements." Ed. Richard A. Landes. New York: Routledge, 2006. 280-86.

Jancovich, Mark. Rational Fears: American Horror in the 1950s. Manchester: Manchester UP, 1996.

King, Geoff, and Tanya Krzywinska. Science Fiction Cinema: From Outerspace to Cyberspace. London: Wallflower, 2000.

Kozlovic, Anton K. "The Cinematic Christ-figure." The Furrow: A Journal for the Contemporary Church 55.1 (2004): 26-30.

"Robert Wise's The Day the Earth Stood Still (1951). Part I: A Religious Film?" Kinema: A Journal for Film and Audiovisual Media 40. Fall (2013): 4-30.

Lewis, James R. UFOs and Popular Culture: An Encyclopedia of Contemporary Myth. Santa Barbara, CA: ABC-CLIO, 2000. 
Lindohf, Jessica. "The Ethos of Modern Apocalyptic Stories: The Use of Judaeo-Christian Narrative in Popular Film." Virtue Ethics and Sociology: Issues of Modernity and Religion. Eds. Kieran Flanagan and Peter C. Jupp. New York: Palgrave, 2001. 186-201.

Long, Laura. "Klaatu, Gort \& I." Starlog 151 (1990): 26-27.

Loughlin, Gerard. "The Man Who Fell to Earth." The Blackwell Companion to Postmodern Theology. Ed. Graham Ward. Oxford: Blackwell Publishers, 2001. 24-47.

Macek, Carl. "The Day the Earth Stood Still." Magill's Survey of Cinema. English Language Film. Volume 2. Ed. Frank N. Magill. Englewood Cliffs, NJ: Salem Press, 1981. 589-91.

Magistrale, Tony. Abject Terrors: Surveying the Modern and Postmodern Horror Film. New York: Peter Lang, 2005.

Matthews, Boris, trans. The Herder Symbol Dictionary: Symbols from Art, Archaeology, Mythology, Literature, and Religion. Wilmette, IL: Chiron, 1990.

McCorry, Keven. The Alien Savior: Klaatu in The Day the Earth Stood Still. http://kevinmccorrytv.webs.com/klaatu.htm. Online March 12, 2014.

Nicolas, Barbara R. "Visions of Faith and Fear." Liguorian 88 (2000): 8-9.

O'Leary, Stephen D. "Apocalypticism in American Popular Culture: From the Dawn of the Nuclear Age to the End of the American Century." The Encyclopedia of Apocalypticism. Volume 3. Apocalypticism in the Modern Period and the Contemporary Age. Eds. Stephen J. Stein. New York: Continuum, 1999. 392-426.

Owen, W. Stuart, P. A. Grist, and R. Dowling, A Dictionary of Bible Symbols. London: Grace Publications Trust, 1992.

Perkowitz, Sidney. Hollywood Science: Movies, Science and the End of the World. New York: Columbia University Press, 2007.

Pettigrew, Terence. Raising Hell: The Rebel in the Movies. Bromley: Columbus Books, 1986.

Pfeiffer, Lee. The Complete Idiot's Guide to Classic Movies. New York, NY: Alpha, 2006.

Rogerson, Peter. "The Mythology of UFO Events and Interpretations: A New Examination." Merseyside UFO Bulletin 5.3 (1972): http://magonia.haaan.com/2008/the-mythology-of-ufo-events-and-interpretationsa-new-examination-peter-rogerson.

Rovin, Jeff. A Pictorial History of Science Fiction Films. Secaucus, NJ: Citadel Press, 1975.

Saleh, Dennis. Science Fiction Gold: Film Classics of the 50s. New York: Comma/ McGraw-Hill, 1979.

Sayre, Nora. Running Time: Films of the Cold War. New York: The Dial Press, 1982.

Shapiro, Jerome F. Atomic Bomb Cinema: The Apocalyptic Imagination on Film. New York: Routledge, 2002 .

Shaw, James. The Day the Earth Stood Still: Dramatizing a Political Tract. Creative Screenwriting 5.4 (1998): 50-53.

Siegel, Richard, and Jean-Claude Suares. Alien Creatures. Sydney: Harper \& Row, 1978.

Sobchack, Vivian. Screening Space: The American Science Fiction Film, $2^{\text {nd }}$ ed. New York: Ungar, 1987.

Stal. "The Day the Earth Stood Still [5 September 1951]." Variety Film Reviews 1949-1953. Volume Eight. New York: Garland Publishing, 1983. npn.

Stone, Jon R. "'Apocalyptic" Themes on the Silver Screen." God in the Details: American Religion in Popular Culture. Eds. Eric M. Mazur and Kate McCarthy. New York: Routledge, 2001. 65-82.

Taylor, Mark D. The Complete Book of Bible Literacy. Wheaton, IL: Tyndale, 1992.

Telotte, J. P. Science Fiction Film. Cambridge: Cambridge UP, 2001. 
Tompkins, Boylston. "Introduction." Alien Creatures. Eds. Richard Siegel and Jean-Claude Suares. Sydney: Harper \& Row, 1978. 7-32.

Torry, Robert. "Apocalypse Then: Benefits of the Bomb in Fifties Science Fiction Films." Cinema Journal 31.1 (1991): 7-21.

von Gunden, Kenneth, and Stuart H. Stock. Twenty All-time Great Science Fiction Films. New York: Arlington House, 1982.

Warren, Bill, and Bill Thomas. Keep Watching the Skies!: American Science Fiction Movies of the Fifties. Volume 1: 1950-195\%. Jefferson: McFarland, 1982.

Worthing, Mark. "Science and Theology - An Historical Overview." Pacific Journal of Theology and Science $1.1(2000): 5-11$.

\section{Author Information}

Anton Karl KOZLOVIC (PhD Flinders) researches in the Screen Studies department, School of Humanities at Flinders University (Adelaide, Australia). His interests include religion-and-film, computer films, and the biblical cinema of Cecil B. DeMille. He has published in journals including Australian Religion Studies Review, Belphegor: Popular Literature and Media Culture, The Film Journal, Journal of Contemporary Religion, The Journal of Religion and Film. 